University for Business and Technology in Kosovo

UBT Knowledge Center

Theses and Dissertations

Student Work

Summer 7-2020

\title{
Studimi i dietës së femrave shtatzënë
}

Flaka Cani

University for Business and Technology - UBT

Follow this and additional works at: https://knowledgecenter.ubt-uni.net/etd

Part of the Food Science Commons

\section{Recommended Citation}

Cani, Flaka, "Studimi i dietës së femrave shtatzënë" (2020). Theses and Dissertations. 19.

https://knowledgecenter.ubt-uni.net/etd/19

This Thesis is brought to you for free and open access by the Student Work at UBT Knowledge Center. It has been accepted for inclusion in Theses and Dissertations by an authorized administrator of UBT Knowledge Center. For more information, please contact knowledge.center@ubt-uni.net. 


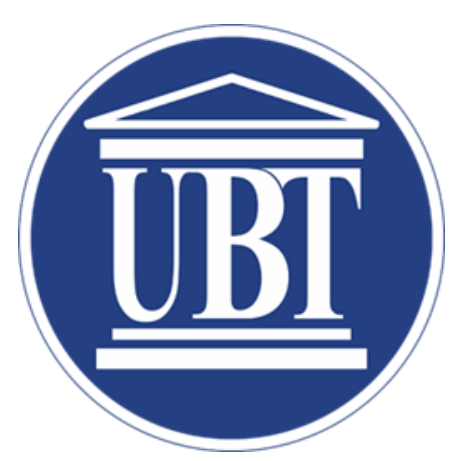

Universiteti për Biznes dhe Teknologji

Departamenti për Shkenca e Ushqimi dhe Bioteknologji

Punimi diplome

Viti akademik 2016/2017

STUDIMI I DIETËS SË FEMRAVE SHTATZËNË

Korrik,2020

Prishtinë 


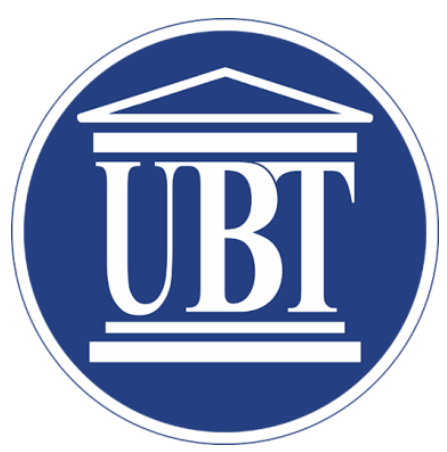

Universiteti për Biznes dhe Teknologji

Departamenti për Shkenca e Ushqimi dhe Bioteknologji

\author{
Punimi diplome
}

Viti akademik 2016/2017

\author{
Flaka Cana \\ STUDIMI I DIETËS SË FEMRAVE SHTATZËNË \\ Mentori: Prof.Dr.Smajl Rizani
}

Korrik, 2020 


\begin{abstract}
Abstrakti
Kjo temë e diplomës studion mënyrën e të ushqyerit të femrave shtatzënë .

Pjesa e kapitullit të parë shpjegon sasinë e makronutrientëve dhe mikronutrientëve të cila nevoiten për femrat shtatzënë dhe nutrientët të cila nevoitet për rritjen e fëmijes.

Pjesa e kapitullit të dytë kemi rekomandimi për dietën e femrave shtatzënë me kolesterol të lartë,diabet apo anemi dhe mënyra e shëndeshme për femrat shtatzënë me dieta vegjetariane apo vegane

Qëllimi i kësaj është përmbledhja e rekomandimeve për mënyrën e të ushqyerit për femrat shtatzënë të cilat kanë sëmundje të caktuara.

Pjesa e praktikës e kësaj teze merret me analizimin e dietës dhe vlerësimi e shprehive e të ushqyerit të femrat shtatzënë.
\end{abstract}

Fjala kyqe: femrat shtatzënë, dietë, nutrientë, vegan, vegjetariane, diabet, anemi, kolesteroli i lartë 
Lista e tabelave

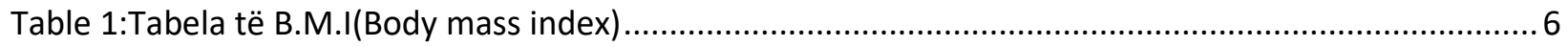

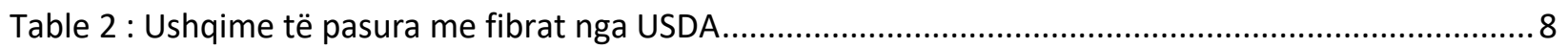

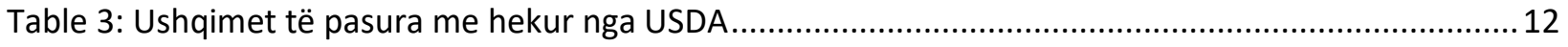

Table 4.Ushqime të pasura me kalcium nga USDA ........................................................................... 13

Table 5.Ushqime të pasura me hekur nga USDA ............................................................................ 14

Table 6.Dieta për femrat shtatzënë me diabet mellitus të tipit 1 ......................................................17

Table 7.Dieta për femrat shtatzënë me gestational diabet mellitus .....................................................18

Table 8.Dieta për femrat shtatzënë me kolesterol i lartë..................................................................... 19

Table 9.Dieta për femrat shtatzënë me anemi ...............................................................................20

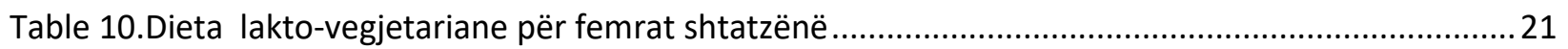

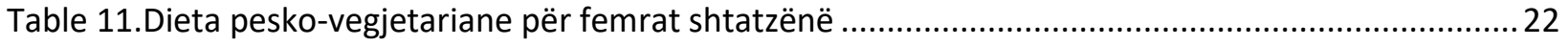

Table 12.Dieta ovo-vegjetariane për femrat shtatzënë........................................................................22

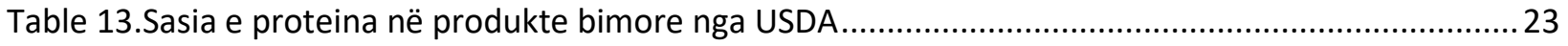

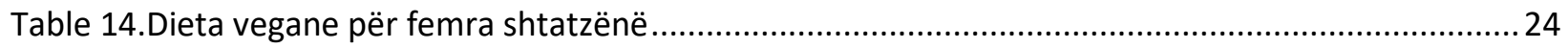

Table 15.Ditar ushqimorë për tre ditë të pacientit të parë ...................................................................25

Table 16.Ditar ushqimore për tre ditë nga pacientja e dytë.................................................................26

Table 17. Ditar ushqimore për tre ditë nga pacienta e tretë...............................................................28

Table 18.Ditar ushqimore për tre ditë nga pacientja e katër ................................................................30

Lista e shkurtesave

BMI - body mass index

USDA - United States Department of Agriculture

WHO - world health organization 


\section{Përmbajtja}

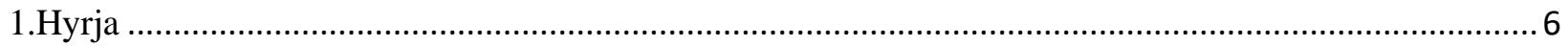

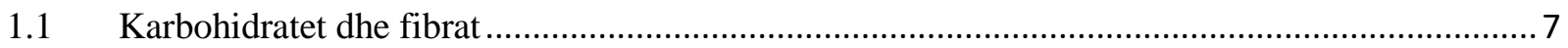

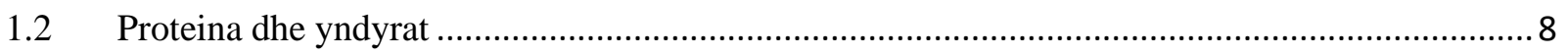

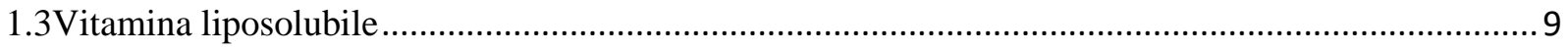

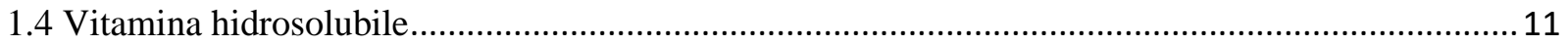

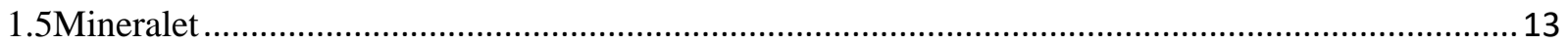

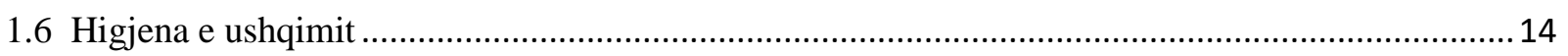

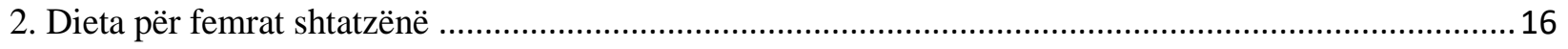

2.1Dieta për femrat shtatzënë me diabetes mellitus të tipit të parë..................................................16

2.2Dieta për femrat shtatzënë me kolesterol të lartë................................................................... 18

2.3Dieta për femrat shtatzënë me anemi ................................................................................... 19

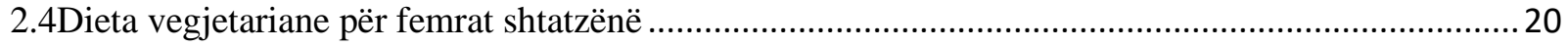

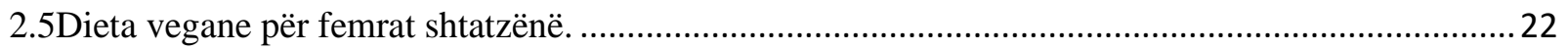

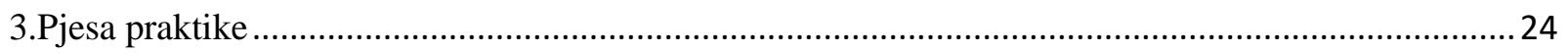

3.1 Ditari ushqimore për tre ditë për pacientën e parë ...................................................................24

3.2 Ditari ushqimore për tre ditë për pacientën e dytë ..................................................................26

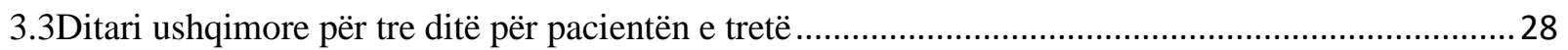

3.4 Ditari ushqimore për tre ditë për pacientën e katërt .................................................................29

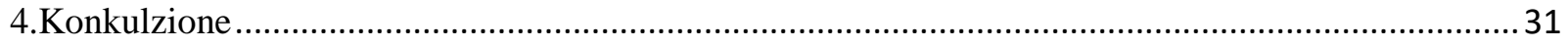

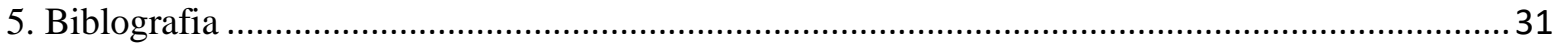




\section{Hyrja}

Gjatë periudhës së shtatzanisë nevojitet të rritet sasia e nutrientëve të cilat nevojiten për rritjen e fetusit.Këshillohet që sasia e ushqimit të ndahet në tre shujta kryesore mëngjes,drekë ,darkë dhe dy midis shujta me sasi më të vogla dhe të hahet në intervale të rregullta.

Kërkesa energjetike për femrat shtatzënë rritet për 340-450kcal/ditë. Ndërsa për femrat shtatzënë të cilat janë nënpeshë,adoleshente apo femra me dy e më shumë fetuse rritet për 500kcal/ditë pasi për këto raste nevojitet më nutrientë. Për femrat shtatzënë shtimi i peshës janë të rekomanduar për nënpeshë 13-18kg, normal 16-18kg dhe mbipeshë 7-11kg. ${ }^{1}$

\begin{tabular}{|l|l|}
\hline & BMI \\
\hline Nënpeshë & $<19 \mathrm{~kg} / \mathrm{m}^{2}$ \\
\hline Peshë normale & $19.5-26 \mathrm{~kg} / \mathrm{m}^{2}$ \\
\hline Mbipeshë & $26-29 \mathrm{~kg} / \mathrm{m}^{2}$ \\
\hline Obezë & $>29 \mathrm{~kg} / \mathrm{m}^{2}$ \\
\hline
\end{tabular}

Table 1:Tabela të B.M.I(Body mass index)

Aktiviteti fizik për femrat shtatzënë ndihmon për shtimin normal të peshës,humbje graduale të peshës pas shtatzanisë .Aktiviteti fizik është terapi e sigurtë për kontrollin e diabetit gestational dhe ndihmon për menaxhimin e dhimbjes së trupit,presion i lartë të gjakut dhe kapsit.Disa aktivitete fizike të sigurta janë ecja,joga,notimi dhe aerobika e lehtë.Për femrat shtatzënë aktiviteti fizike rekomandohet të ketë intensitetin mesatarë me total 30 minuta në ditë dhe të largohen aktivitete fizike që shkaktojnë lodhje të madhe. Aktivitetet të larta apo sportet që kanë rritje të rrezikut të rënies dhe traumës të abdomenit duhen të limitohen apo të largohet.Raste për cila nuk rekomandohet aktiviteti fizikë është nëse kanë simptoma sikur gjakderdhje,marramendje,dhimbje koke dhe lodhje të muskujve. ${ }^{2}$

\footnotetext{
${ }^{1}$ Handbook of Nutrition and Pregnancy ,2008

2 Proper Maternal Nutrition during Pregnancy Planning and Pregnancy:healthy start in life,2017
} 


\subsection{Karbohidratet dhe fibrat}

Karbohidratet janë një burim kryesor i energjisë për nënën dhe fetusin. Sasia e karbohidrateve nuk ndryshon prej femrat joshtatzënë të cila rekomandohet që duhet të jetë 50-60\% te energjisë ditore. Rekomandohet të merren ushqime me fibra sikur drithërat intregale,oriz intregal,tërshëra,buka me miell intregal,pasta,quinoa,amaranth.Gjithashtu, rekomandohet që shujta ditore të jenë të mbushur me pemë të ndryshme dhe perime.

Nuk këshillohet të përdoret dieta sipas të cilës rekomandohet konsumimi i sasisë se vogël të karbohidratet pasiqë ndikon në rritjen të fetusit.Sasia e sheqerit të bardhë duhet të limitohet në 5\% të kerkesës energjetike ditore ose $25 \mathrm{~g}$. Lëngjet e frutave,pijeve të buta dhe ujërat me shije duhen të limitohet për të zvogëluar përdorimin të sheqerit të bardhë .

Femrat të cilat kanë diabet duhen të kenë kujdes me konsumin e ushqimeve të cilat mund të rrisin glukozës në gjak pasi plancenta formon hormone të cila rrisin rezistencën e insulinës e cila mund të shkaktoj probleme me sasinë e glukozës në gjak.Me anë të dietës dhe aktiviteteve fizike të lehta mund të ndihmoj në rregullimin e glukozës.

Fibrat nevojiten për funksionimin normal të zorrëve dhe ndihmojnë të parandalojnë kapsin dhe të zvogëlojnë riskun për hemorroidet për femrën shtatzënë dhe poashtu zvogëlon rrezikun për diabetin e shtatzanisë.Sasia e fibrave rekomanduar është 30-35g . ${ }^{3}$

Ushqime të pasura me fibra janë legumet sikur pasuli i bardhë,pasuli i kuq,pasuli i zi,thjerrëza të kuqe,thjerrëza të kaftë dhe tërsherë ,farat,frutat arrore sikur bademi,arra,lajthia

\footnotetext{
${ }^{3}$ Proper Maternal Nutrition during Pregnancy Planning and Pregnancy,2017
} 


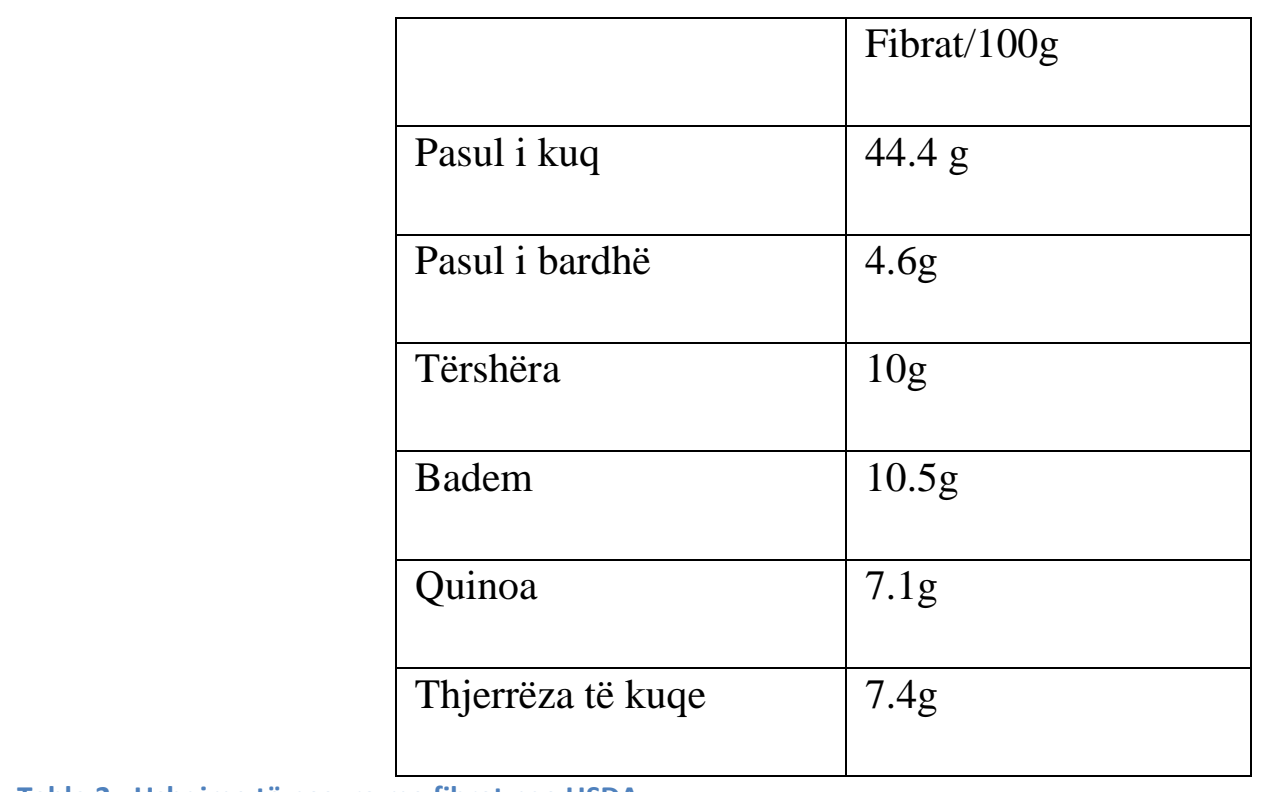

Table 2 : Ushqime të pasura me fibrat nga USDA

\subsection{Proteina dhe yndyrat}

Sasia e proteinave të cilat nevojiten për femrat shtatzënë në pjesën e parë të shtatzanisë nuk ndryshon prej femrat joshtatzënë te cila është $0.8-1.0 \mathrm{~g} / \mathrm{kg}$ për ditë. Ndërsa në pjesën e dytë e shtatzanisë nevojitet $1.1 \mathrm{~g} / \mathrm{Kg}$ shtohet $25 \mathrm{~g}$ dhe sasia e plotë është $70-75 \mathrm{~g}$ në ditë. Ndërsa sasia e vogël e konsumimit të proteinave mund të jetë e lidhur me lindje me peshë të vogël pasi aminoacidet nevojiten për krijimin e qelizave të reja.

Sasia e nevojitur e proteinave rritet për ndihmën e rritjes së fetusit,zhvillimin e plancentës, rritjen e volumit të gjakut dhe rritjeve të indeve tek nëna.Proteinat vijnë nga produkte shtazore mish $\mathrm{i}$ kuq,mish pule,peshkë,vezët,dhe produktet të bylmetit dhe nga produkte bimore të cilat janë pasul i kuq,pasul i bardhë,bizele,soja,tofu,tempeh dhe thjerrëza dhe qiqra.

Sasia e yndyrës për femrat shtatzënë nuk ndryshon nga femrat joshtatzënë dhe rekomandohet të jetë 30\% të energjisë nevojshme ditore. Për femrat shtatzënë rekomandohet të limitohet sasia e yndyra me sasi të lartë me yndyra të ngopura nga ushqime sikur margarina,gjalpë dhe vaj palme.Ushqime me acide të pangopura sikur omega-3 bashkë me omegën-6 nevojitet për zhvillimin të trurit të fetusit dhe zvogëlon risk të lindje të hershme. Sasia e omegës-3 të rekomanduar janë 200-300mg/ditë të cila mund përmbushen me dy shujta të peshkut në javë. 
Mënyra që përgaditet peshku poashtu ka rëndësi dhe rekomandohet të jete pjekur apo e zier ndërsa peshkë të tymosur nuk rekomandohet. Omega-3 gjendet në sardine,salmon,arrat,lajthia,soja. $\alpha-$ linolenik gjendet në tofu,fara kungulli,fara të lirit,soja dhe arra. Për sumplemente të omega-3 nuk rekomadohet të merren hapa të vajit të peshkut pasi mund të kenë të lartë të vitaminës A .

\subsection{Vitamina liposolubile}

Vitamina liposolubile janë vitamina të cilat janë të tretshme në yndyrë.Vitamina liposolubile janë vitamina A,D,E,F dhe K.

Vitamina D ndihmon për zhillimin e sistemit imunitar, eshtrave dhe të trurit të fetusit,Ajo merr pjesë në përthithjen e kalciumit,ndërtimin e eshtrave dhe punën e veshkave.Vitamina $D$ sintetizohet në organizmin e njeriut me ndihmën e rrezeve UV nga drita e diellit.Sinteza e vitamins D bëhet në lëkurë nga kolesteroli (7-dehidrokolesterol) ne holokalciferol me anë të rreze UV.Deficienta të vitamin D mund të ketë efektë negative të zhvillimin e indit të eshtrave të fetusit, e cila mund të mund të shkaktojnë osteoporozës.Për nënën deficientat e vitaminën D mund të shkaktojnë lindje parakohë, problem me rritje të fetusit ,resistenca të insulinës dhe preeklapsia.Sasia e vitaminën D e cila nevojitet për femrat shtatzënë është 600-800 IU. ${ }^{4}$ Ushqime të pasura me vitamin D janë sardinet,mëlqia,vezët,tofu,salmon,djath,qumësht.

Vitamina E është grup i substancave të njohura si tokoferolet dhe $\alpha$-tokoferol është më aktive.Sasia e rekomanduar për femrat shtatzënë nuk ndryshon nga femrat joshtatzënë dhe është 7-11 mg të $\alpha$ TE .Deficienta e vitaminës është e rrallë por mund të shkaktoj abort të fetusit.

Ushqime të pasura me vitamina $E$ janë vaj lulediellit,vaj misri,vaj ulliri,margarina,gjalpi ,fruta arrore(arra,badem,lajthi) dhe fara(lulediellit,liri,susam,kungulli).

Vitamina K ndihmon kuagulimin normal të gjakut dhe sintetizohet në zorrë .Disa medikamente dhe mund të inteferojnë me metabolizimit të vitaminës $K$.Medikamentet për epilepsi mund të inhiboj transportin plancental të vitaminës $K$ të cila tek fetusi ndikon në sintezën e faktorëve të kuagulimit.Femrat shtatzënë me epilepsi duhen të marrin këshilla shëndetsore nga mjeku nese

\footnotetext{
${ }^{4}$ Proper Maternal Nutrition during Pregnancy Planning and Pregnancy,2017
} 
është nevojshme të merret suplemente të vitaminës K.Gjatë marrjes së antibiotikëve të japur nga doktori këshillohet marrja e suplementeve të vitaminës $\mathrm{K}$.

Ushqime të pasura me vitaminës K gjenden në perime sikur spinaqi,lakra,qepët,kale,brokolli dhe gjenden në produkte shtazore sikur djathi,jogurti,kombucha.Rekomandohet së paku tre shujta ditore të perimeve sidomos perimet gjethore sikur spinaqi,kale,lakra.

Sasia e rekomanduar të vitaminës K nuk ndryshon dhe është $60 \mu \mathrm{g} / \mathrm{ditë}^{6}$

Vitamina A në produkte shtazore gjendet në formë të retinolit dhe tek bimët gjendet si formë karatenoide, por $\beta$-karoten është forma e vetme aktive. Vitamina A përfshihet në zhvillimin embrional,ekspresionin gjenetik,funksionin imunitar dhe rimodullimin e eshtrave.

Nuk rekomandohet për femrat shtatzënë të ushqehen me sasi të mëdha të mëlqisë apo produkte me mëlqisë pasi që ato kanë sasi të larta të vitaminit A në formë retinolit. Vitamina A në formë retinoli në sasi të mëdha mund të efekt teratogjenikë dhe shkakton defekte të lindjes. Rekomandohet që vitamina A të merret nga fruta dhe perime sikur karota,kungulli,speca të kuq, spinaqi dhe kajsia të cila gjenden si forma të $\beta$-karotenit. Absorbimi i $\beta$-karotenit nga frutat dhe perimet rritet me pjekje,zirje,prerje dhe me shtim të yndyrës .Sipas konsumi e rekomanduar për femrat shtatzënë të

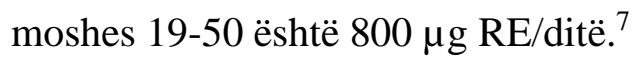

Vitamina $\mathrm{F}$ ose ndryshe omega-3 janë acide yndyrore të pangopura dhe ky karakterizohet me lidhje dyfishe trelidhje atomesh larg grupit metil në strukturën kimike.Omega-3 gjendet në produktet me yndyrë, sikur në produkte shtazore, sikur në peshku tuna,troftë,salmon dhe në fruta arrore (arra,badem,lajthi) dhe fara të lirit ,lulediellit.Ajo gjendet edhe në vaj të peshkut,vaj liri.

Omega-3 rekomandohet të merret nga peshqit sikur tuna,salmon troftë,makarel,karp por gjendet edhe në karkaleca dhe ushqime të detit .Ajo mund të merret nga produkte bimore si fruta arrore dhe fara të lirit.

\footnotetext{
${ }^{5}$ Food and Nutrition Guidelines for Healthy Pregnant and Breastfeeding Women,2006

${ }^{6}$ Food and Nutrition Guidelines for Healthy Pregnant and Breastfeeding Women,2006

${ }^{7}$ Food and Nutrition Guidelines for Healthy Pregnant and Breastfeeding Women,2006
} 
Omega-3 është esencial për mbatjen në balance të hormone sikur progesteroni, të cila si hormone ndihmojnë në funksionet sikur presioni i gjakut,reagim alergjike,reagim imunitar,funksionin e veshkave ,sistemit të tretjes dhe hormone tjera. ${ }^{8}$ Ajo poashtu ndihmon zvogëlimin e riskut të paralindjes,pre-clampsia dhe rritje e peshës e fëmijës të lindur.

Sasia e rekomanduar është $300 \mathrm{mg} /$ ditë DHA. ${ }^{9}$

\subsection{Vitamina hidrosolubile}

Vitamina hidrosolubile janë vitaminat të tretshme me ujë dhe ato vitaminat jane komplekse të vitaminës $B$ ( vitamina $B_{1}, B_{6}, B_{9}, B_{3}, B_{12}$ ), vitamina $C$.

Vitamina $B_{1}$ është koenzimës përfshirë në metabolizimi e karbohidrateve, proteinave dhe yndyrës .Deficienta në vitaminës $B_{1}$ ndikon në rritjes të fetusit dhe e lidhur me rritjen e rrezikut për preclampsia.Deficienta e vitaminës $\mathrm{B}_{1}$ mund të jetë nga limitimi i konsumimit të ushqimeve sikur drithërat dhe bukes dhe përdorimi i alkoholit.Kërkesa për tiaminës rritet për femrave shtatzënë për rritjen e fetusit dhe sasia e rekomanduar është $1.4 \mathrm{mg} /$ ditë.

Riboflavin është koenzimës përfshirë në procese metabolike. Sasia e rekomanduar për femrat shtatzënë prej moshës 19-50 është $1.4 \mathrm{mg} /$ ditë

Vitamina $\mathrm{B}_{6}$ (Piridoksina) bën pjesë në sintezën e hemit dhe në vendosjen e hekurit në hemoglobinë.Ajo poashtu ndihmon në procesin e transaminimit i cila është proces themelore në metabolizmin e aminoacideve sidomos triptofanit, dhe metabolizmi e acideve yndyrore të pangopura.Ushqime të pasura me vitaminën $\mathrm{B}_{6}$ gjenden në mish të kuq,mish pule,peshqi(tuna,salmon),legume,tërshërë,banane, kumbulla, avokade dhe patate.Nuk nevojitet suplemente të vitaminë $\mathrm{B}_{6}$ pasi që ajo mbulohet me ushqimi.Deficienta e vitaminës $\mathrm{B}_{6}$ është e rrallë por zakonisht vërehet te femrat shtatzënë të cila kanë deficientat të vitaminave tjera dhe deficienta të proteinës.

Sasia e rekomanduar për femrat shtatzënë është 1.9 mg/ditë, dhe sasia e lartë është toksike. ${ }^{10}$

\footnotetext{
${ }^{8}$ Why is Omega-3 Fish Oil Important During Pregnancy?

${ }^{9}$ Proper Maternal Nutrition during Pregnancy Planning and Pregnancy,2017

${ }^{10}$ Food and Nutrition Guidelines for Healthy Pregnant and Breastfeeding Women,2006
} 
Acidi folik ka rol në zhvillin e eritroblasteve dhe qelizave tjera në palcën kurrizore dhe merr pjesë në sintezën e proteinave,purinave dhe pirimidinat dhe bashkë me vitamina $B_{12}$ merr pjesë në sintezën e acideve nukleike dhe hemoglobinës. Acidi folik gjendet në mëlqi,veshkë,qumësht,vezë dhe perime sikur spinaqi,karfioli,lakra,speca,brokolli,avokado. Kur kemi të bëjmë me acidit folik rekomandohet që të merret për femrat që dëshirojnë të mbesin shtatzënë duhet të konsumohet për 400mg/ditë dhe dietë të pasura me acidin folik ${ }^{11}$

Vitamina $\mathrm{B}_{12} \mathrm{ka}$ rol në konvertim e homocisteinës në metionin, prodhimin e qelizave të kuqe ,ADN-së dhe funksionimin normal të sistemit nervorë.Vitamina $\mathrm{B}_{12}$ sintetizohet nga bakteriet që gjenden në produkte shtazore sikur mishi i kuq, mishi i pulës,vezët,peshku,qumështi dhe produkte e bylmetit.Femrat shtatzënë të cila kanë anemia megablastike dhe janë vegane rekomandohet suplemente të vitaminës $B_{12}$. Sasia e rekomanduar për femrat shtatzënë është $2.6 \mu \mathrm{g} / \mathrm{ditë}$.

Vitamina C është ko-faktor për enzimat të cilat përfshihen në sintezën e kollagenit,neurotransmitorë dhe carnitinë . Vitamina $\mathrm{C}$ bën përthithjen e hekurit dhe kalciumit dhe është e domosdoshëm për funksionin e eshtrave.Ushqime të pasura me vitaminën C janë specat,lakërat,limonat,spinaqi,dredhëzat,protokalli,grejtfuti. Nevoja ditore për femra shtatzënë të vitaminës C është 60mg/ditë. ${ }^{12}$

\begin{tabular}{|c|c|}
\hline & Vitamina $\mathrm{C} / 100 \mathrm{~g}$ \\
\hline Speci & $77.6 \mathrm{mg}$ \\
\hline Lakëra & $36.6 \mathrm{mg}$ \\
\hline Limoni & $53 \mathrm{mg}$ \\
\hline Dredhëza & $56 \mathrm{mg}$ \\
\hline Spinaqi & $28.2 \mathrm{mg}$ \\
\hline
\end{tabular}

Table 3: Ushqimet të pasura me hekur nga USDA

\footnotetext{
${ }^{11}$ Proper Maternal Nutrition during Pregnancy Planning and Pregnancy,2017

${ }^{12}$ Food and Nutrition Guidelines for Healthy Pregnant and Breastfeeding Women,2006
} 


\subsection{Mineralet}

Për femrat shtatzënë rritet sasia e nevojshme të kalciumit, por trupi i nënës absorbon sasi të rritur të kalciumit me anë të proceseve fiziologjike keshtu rekomandohet të merret në sasi të njejtë me femra joshtatzënë te cila sasia e rekomanduar është $1000 \mathrm{mg} /$ ditë. ${ }^{13}$ Kalciumi merret nga qumështi i lopës dhe nga produkte të qumështit sikur djathi,kefiri,jogurti,pluhuri i qumështit.

Kalciumi për femrat me intolerancë të laktozës mund të merret në qumësht të tërshërës me kalcium,qumësht bademi,legumet,fara të kungullit dhe peshqi me eshtra sikur sardinet.Kalciumi ndihmon për krijimin e indit eshtrorë apo eshtra të shëndeshme të fetusi dhe akumulon $30 \mathrm{~g}$ dhe $25 \mathrm{~g}$ gjendet në sistemi skeletorë.

\begin{tabular}{|c|c|}
\hline & Calcium/100g \\
\hline Tofu & $118 \mathrm{mg}$ \\
\hline Qumështi & $104 \mathrm{mg}$ \\
\hline Sardinet & $4073 \mathrm{mg}$ \\
\hline Farat chia & $631 \mathrm{mg}$ \\
\hline Jogurti & $133 \mathrm{mg}$ \\
\hline
\end{tabular}

Jodi nevojitet për zhvillim sistemin nervorë qëndror të fetusit dhe për sintezën të hormoneve tiroide tek femrat.Sasia e rekomanduar ditore për femrat joshtatzënë dhe gjatë shtatzanisë dhe gjatë kohës të laktacionit është 150-250 $\mu \mathrm{g}$, e cila mund të merret edhe suplemente të formuluara me subtancë aktive kalium jodi. Ndërsa sasia maksimale e lejuar për femrat shtatzënë dhe gjatë laktacioni është $600 \mu \mathrm{g} /$ ditë, ndërsa >1100 $\mu \mathrm{g} /$ ditë konsiderohet e pasigurtë. ${ }^{14} \mathrm{Për}$ femrat shtatzënë me sëmundje të gjëndrës tiroidet doza duhet të konsultohet me endokrinologë.Suplemente të algave nuk rekomandohet për shkak të mundësisë mbidozë të jodit e cila ka ndikim negativë të funksionit te gjëndra tiroide. Ushqime të pasura me jod janë produkte të detit sikur peshqit( tuna,sardinet,salmon,codi ), fruta të detit dhe brusnica.

Zinku është një ndër minerale të cilat rritet për femrat shtatzënë dhe në krahasim me femrat joshtatzënë ajo ndryshon për 38\%.Ajo është përfshihet në sintezën e acidit dezoksiribonukleikë , acidi ribonukleik dhe ribozomet dhe nevojitet për ekspresionin të gjenit,diferencimin dhe

\footnotetext{
${ }^{13}$ Food and Nutrition Guidelines for Healthy Pregnant and Breastfeeding Women,2006

14 Proper Maternal Nutrition during Pregnancy Planning and Pregnancy,2017
} 
replikimin e qelizës.Per femrat shtatzënë është rast i rrallë deficienta e zinkut dhe është në raste të Acrodermatitis enteropathica e shkaktuar nga mutancionet gjenetike të cila janë përgjegjëse të prodhimit të proteinës të membranës e cila lidh zinkun .Ushqime të pasura me zink janë drithërat,mishi i shpendëve, frutat e detit,drithërat intregale, bademi,arrat braziliane, arrat indiane ,vezët,kakao.

Sasia e nevojshme e hekurit rritet gjatë shtatzanisë, dhe rritet më shumë gjatë pjesën e dytë të shtatzanisë .Gjatë pjesës të dytë shtatzanisë sasia e volumi i gjakut dhe numri i eritrocitet rritet dhe për fetusin dhe plancentën nevojitet më shumë hekur. Ndërsa sasia e hekurit dhe hemoglobinës rritet gjatë shtatzanisë pasi nuk kemi humbje të gjaku .Hekuri nevojitet për krijimin e qeliza të gjakut për fetusin dhe për gruan .

Ushqime të pasura me hekur janë mishi i kuq,mishi i pulës,vezët,legumet,frutat arrore,drithërat intregale,spinaqi. Deficienta të hekurit mund të shkaktoj lindje parakohe dhe peshë të vogël të fëmijës.Ndërsa anemia në pjesën e parë të shtatzanisë mund të shkaktoj lindje parakohe,probleme në zhvillimin e fetusit dhe peshë e vogël të fëmijes dhe bën zvogëlimin e imunitetit .Suplemente të hekurit rekomandohet për femrat shtatzënë me anemi dhe sasia varet nga doktori.

\begin{tabular}{|c|l|}
\hline & Hekur(Fe)/100g \\
\hline Vezë & $1.59 \mathrm{mg}$ \\
\hline Spinaq & $2.35 \mathrm{mg}$ \\
\hline Salmon & $0.51 \mathrm{mg}$ \\
\hline Sardine & $2.92 \mathrm{mg}$ \\
\hline Tuna & $1.39 \mathrm{mg}$ \\
\hline Tofu & $1.37 \mathrm{mg}$ \\
\hline Pasul & $1.54 \mathrm{mg}$ \\
\hline Tërshërë & $4.5 \mathrm{mg}$ \\
\hline Fara kungulli & $3.67 \mathrm{mg}$ \\
\hline
\end{tabular}

Table 5.Ushqime të pasura me hekur nga USDA

\subsection{Higjena e ushqimit}

Te femrat shtatzënë zvogëlohet sistemi imunitar dhe rritet rreziku për helmim ndaj ushqimit. Higjena e ushqimit duhet të respektohet sidomos kur kemi të bëjmë me produkte ushqimore të cilat kanë risk për helmime ushqimore sikur produktet shtazore (mishi lopës,mishi i pulës,vezët dhe peshqit). Uji i konsumuar duhet të vij nga burimi me sistem të sigurtë dhe të jetë i analizuar.

Toksoplasmosis është infeksion e shkaktuar nga Toxoplasma gondii e cila gjendet në mish, tokë ose ujë të kontaminaur me cist të Toxoplasma gondii.Për femrat shtatzënë zakonisht nuk ka 
simptoma dhe mund të vërehet, por për fetusin mund të shkaktoj probleme serioze.Ekspozimi gjatë pjesës së parë të trisemetritë shkakton probleme më serioze ndërsa më vone kemi me pak, dhe zakonisht pjesët e ndikuar te fetusi janë sytë dhe truri të disa të shkaktojnë janë verbërim,deficit neurologjik,epilepsi dhe simtomat mund të paraqitet në lindje ose më vonë.

Rekomandohet për femrat shtatzënë duhet:

- mish të gatuhet mirë dhe jo të hahet mish i papjekur apo mish i jo pjekur komplet ku mund të vërehet ende prani të gjakut.

- largohen nga ujë apo tokë e kontaminuar dhe ushqimet të cila vijnë nga tokë e kontaminuar me ciste

- të mos merret me largimin e nevojes së macave,

- të mos konsumoj fruta dhe perime jo të lara,

- dhe të mos merret me kopshtari

Listeria monocytagenes gjendet në produktet të cilat nuk janë vendosur në kushte adekuate për ruajte dhe rekomandohet të kemi higjenë adekuate kur kemi të bëjmë me produkte shtazore sikur mishi i kuq,mishi i pulës dhe peshqi. Listeria monocytagenes mund të shumohet në temperaturat -1.5 deri $50^{\circ} \mathrm{C}$.

Për eliminim të rrezikut ndaj helmimit nga Listeria monocytagenes duhet që:

- pemët dhe perimet duhen të lahen mirë dhe kemi kujdes gjatë gatimit

- Ushqimi i gatuar të ri-nxehet në temperaturë të lartë(së paku $70{ }^{\circ} \mathrm{C}$ )

- mos konsumohet qumështi i jopasterizuar dhe djathërat me qumësht të jopasterizuar p.sh Brie,Camembert

- $\quad$ mishi i papjekur nuk duhet të vendoset bashkë me ushqime të gatuar për të mos pasur kontaminim

- mishi gjatë procesit të marinimit ose mish i ngrirë të mos rrij në temperature të dhome por në frigorifer 
- $\quad$ të mos konsumohet peshqit të tymosur,të pagatuar,vezë të papjekur,

Djathërat të forta të bërë nga qumështi i pasterizuar mund të konsumohet.

Për eliminim e rrezikut për helmim nga Salmonella rekomandohet që veza të gatuhet komplet dhe pjesa e kuqe e vezës të mos jetë as pjesërishtë e papjekur dhe produktet të bërë nga vezët e paziera sikur majonezi shtepiakë të mos konsumohet.

\section{Dieta për femrat shtatzënë}

Femrat shtatzënë mund të kenë sëmundje të cila paraqiten gjatë shtatzanisë sikur Gestational diabetes mellitus apo diabeti i shtatzanisë.Por mund të kemi raste të cila kanë sëmundje sikur diabet mellitus të tipit 1,me kolesteroli i lartë,anemi dhe sëmundje kronike duhen të kenë dieta specifike të cila ndihmojnë gjatë shtatzanisë.

\subsection{Dieta për femrat shtatzënë me diabetes mellitus të tipit të parë}

Diabeti i tipit 1 është diabeti i varur nga insulina për shkak se pankreasi nuk prodhon sasi të nevojshme të insulinës. Truri vazhdon të përdorë glukozë të përfituar nga ushqimet,ndërsa pjesa e tjetër e trupit përdorë yndyra si burim energjie dhe niveli i glukozës rritet por nuk mund të depozitohet në formë glikogjeni por del me anë të jashtëqitje, e cila do të ketë sasi të lartë glukoze. Femrat shtatzënë me diabetes mellitus të tipit të parë ju nevojitet dietë me anë te cilës mund të kenë sasi normale të glukozës në gjak. Sasia e karbohidrateve nuk ndryshon për femrat shtatzënë me diabet dhe rekomandohen shujta të shpeshta me sasi të vogla dhe ushqime të pasura me fibra sikur buka me miell intregal,tërshërë,pasta intregale,pasta,bulgur,orizi i kaftë.Rekomandohet që të merren ushqime me fibra dhe ushqime bimore të pasura me proteina sikur pasul i bardhë,pasul i kuq,bizele,thjerrëza dhe qiqra.Mishi i kuq rekomandohet dy herë në javë që të limitohet sasia e yndyrës të ngopur.Mish i pulës rekomandohet dy dhe tre herë në javë sidomos mish i bardhë i pulës dhe peshku rekomandohet dy herë në javë sikurse salmoni,trofta,sardinet,tuna

Të largohen nga ushqimet të pasuara me sheqer të bardhë sikur xhemi,marmelada,pije freskuese,jogurte me shije,musli dhe ushqime të pasura me glukoza.Sasia e suplementeve të cila nevojiten nuk ndryshon nga femrat shtatzënë të cilat nuk kanë diabet. 


\begin{tabular}{|l|l|l|l|l|}
\hline Mëngjesi & Midis shujte & Drekë & Midis shujte & Darkë \\
\hline $\begin{array}{l}\text { Bukë intregale me } \\
\text { vezë dhe djath }\end{array}$ & Fara luledielli & $\begin{array}{l}\text { Bizele me perime } \\
\text { Sallatë }\end{array}$ & $\begin{array}{l}\text { Tërshërë me fara } \\
\text { chia }\end{array}$ & Supë të thjeshtë \\
\hline $\begin{array}{l}\text { Vezë dhe sallate } \\
\text { me pak bukë } \\
\text { intregal }\end{array}$ & Sallatë fruta & $\begin{array}{l}\text { Mish pule me oriz } \\
\text { intregal }\end{array}$ & Fara kungulli & $\begin{array}{l}\text { Makarona } \\
\text { intregale }\end{array}$ \\
\hline
\end{tabular}

Table 6.Dieta për femrat shtatzënë me diabet mellitus të tipit 1

\subsubsection{Dieta për femrat shtatzënë me Gestational diabetes mellitus}

Gestational diabetes mellitus është formë diabetit të paraqitet gjatë shtatzanisë dhe zakonisht largohet pas lindjes, por ajo mund të rritë riskun për zhvillimin e diabetit tipit të dytë.Gjatë kohës të shtatzanisë plancenta prodhon hormone që ndihmojnë në zhvillimin e fëmijës dhe këto hormone poashtu bllokojnë punën e insulines dhe kjo quhet rezistenca e insulinës.Kjo rezistencë e insulinës bën që nevoja e trupit për insulinë të rritet për disa herë dhe niveli i sheqerit në gjak rritet pasi insulina është përgjegjëse e ruajtes të sasisë të glukozës në gjak.Poashtu vërejmë se niveli i glikemisë është më i lartë tek fetusi i femrat shtatzënë me diabet mellitus.

Sugjerohet për femrat me gestational diabetes mellitus të matet niveli i glukozës dhe sipas American Diabetes Assocation sasia e glukozës rekomandohet të jetë:

- Para shujtës sasia e glukozës të jetë 95 mg/dl ose më pak

- Një orë pas shujtës sasia e glukozës të jetë 140 mg/dl ose më pak

- Dy orë pas shujtës sasia e glukozës të jetë $120 \mathrm{mg} / \mathrm{dl}$ ose më pak ${ }^{15}$

Aktiviteti fizik të lehtë mund të ndihmoj të mbaj niveli e glukozës bashkë me dietë të shëndeshme.Për femrat shtatzënë me diabeti të shtatzanisë rekomandohet shujta të shpeshta me sasi të vogla dhe karbohidratet të pasura me fibra sikur buka me miell intregal,tërshërë,pasta intregale,pasta,bulgur,orizi i kaftë.

${ }^{15}$ American Diabetes Association 
Sasia e yndyrës të ngopura të limitohet dhe të largohen nga ushqimet të pasura me sheqer të bardhë sikur xhem,marmeladë,pije freskuese,jogurt me shije,musli dhe ushqime të pasura me glukozë.

Rekomandohet që proteinat të merren nga pasuli,thjerrëzat,bizele dhe qiqra pasi janë ushqime të pasura me fibra dhe nga produkte shtazore peshkë,mish pule,vezët dhe mish të kuq.

Peshku rekomandohet dy herë në javë sikurse salmoni,trofta,sardinet dhe tuna .

Rekomandohet që shujtat ditore të jenë të pasura me perime dhe pemë.

\begin{tabular}{|l|l|l|l|l|}
\hline Mëngjes & $\begin{array}{l}\text { Midis } \\
\text { shujta }\end{array}$ & Dreka & Midis shujta & Darkë \\
\hline $\begin{array}{l}\text { Bukë intregale me vezë } \\
\text { dhe djath me pak } \\
\text { yndyrë }\end{array}$ & $\begin{array}{l}\text { Fruta } \\
\text { arrore }\end{array}$ & $\begin{array}{l}\text { Supë kungulli } \\
\text { Oriz me perime }\end{array}$ & Fara kungulli & Makarona intregale \\
\hline $\begin{array}{l}\text { Sallatë të thjeshtë me } \\
\text { vezë të zier }\end{array}$ & $\begin{array}{l}\text { Sallatë } \\
\text { frutave }\end{array}$ & $\begin{array}{l}\text { Bullgur me } \\
\text { perime } \\
\text { Supë këpurdhe }\end{array}$ & Fruta arrore & Sardine dhe bukë intregale \\
\hline
\end{tabular}

Table 7.Dieta për femrat shtatzënë me gestational diabet mellitus

\subsection{Dieta për femrat shtatzënë me kolesterol të lartë}

Kolesteroli nevojitet për prodhimin dhe funksionimin e estrogenit dhe progesteronit të cilat janë vitale për femrat shtatzënë.Te disa femra sasia e kolesterolit rritet gjatë pjesë së dytë dhe tretë të trisemestrit, dhe zvogëlohet 4-6 javë pas lindjes.Për femrat me kolesterol të lartë rekomandohet të ndryshohet medikamentet për kolesterol pasi disa medikamente nuk janë përshtatshme për femrat shtatzënë.Menaxhimi i kolesteroli gjatë shtatzanisë mund të behet me dieta.

Yndyra të pangopura dhe omega-3 të cilat gjenden në avokado,fruta arrore(lajthi,arra,badem,arra indiane) dhe fara sikurse chia,kungulli,luledielli,liri ndihmon në zvogëlimin e kolesterolit dhe zhvillimin e trurit dhe sistemit nervorë të fetusit.

Limitimi i ushqimeve të fërguara, ushqimeve të procesuara,ëmbëlsirave, mishit të kuq,gjalpës dhe margarinës për zvogëlimin e sasive të yndyra të ngopura. 
Mish pule rekomandohet për 2-3 herë në javë sidomos mishi i bardhe i pulës dhe të largohet lëkura për zvogëlimin e yndyrës së ngopur.

Peshku rekomandohet për dy here në javë, dhe një herë në javë peshqi të yndyrshëm sikurse salmoni,tuna,trofta.

Suplemente të omeges-3 rekomandohen të merren, dhe ajo mund të gjendet në fara liri,fara kungull,fara lulediellit.

\begin{tabular}{|c|c|c|c|c|}
\hline Mëngjesi & Midis shujtë & Drekë & Midis shujtë & Darkë \\
\hline Vezë dhe djath & Fara kungulli & $\begin{array}{l}\text { Supë perime } \\
\text { Sallatë pule }\end{array}$ & Fruta arrore & $\begin{array}{l}\text { Buke intregale } \\
\text { me tuna }\end{array}$ \\
\hline $\begin{array}{l}\text { Tërshërë me } \\
\text { kakao }\end{array}$ & Fruta arrore & $\begin{array}{l}\text { Bizele } \\
\text { Supe këpurdhe }\end{array}$ & Sallatë frute & $\begin{array}{l}\text { Bukë misri dhe } \\
\text { djath }\end{array}$ \\
\hline $\begin{array}{l}\text { Jogurtë fruta dhe } \\
\text { tërshërë }\end{array}$ & Sallatë frute & $\begin{array}{l}\text { Oriz intregal me } \\
\text { këpurdha } \\
\text { Supë }\end{array}$ & Fara lulediellit & Sallatë \\
\hline
\end{tabular}

Table 8.Dieta për femrat shtatzënë me kolesterol i lartë

Në tabelë kemi një shembull të menyrës të të ushqyerit për femrat shtatzënë me kolesterol të lartë.Karbohidratet rekomandohet të merren nga ushqime me fibra sikur bukë intregale,oriz intregal ,bukë misri.Proteinat të merren nga mishi i bardhë i pulës,bizelet,pasuli por në sasi të limituar të vezëve se paku katër në javë dhe mish lope dy herë në javë.

\subsection{Dieta për femrat shtatzënë me anemi}

Anemia e lehtë te femrat shtatzënë është e zakonshme pasi që sasia e gjakut rritet poashtu nevoja për hekur,vitaminë $\mathrm{B}_{9}$ dhe vitaminë $\mathrm{B}_{12}$.

Ushqimet të pasura me vitamina $B_{12}$ gjenden në produkte shtazore sikurse vezët,mish pule,mish të kuq,peshqi . Për femrat shtatzënë të cila janë vegane duhen të merren suplemente të vitaminë $B_{12}$ të përmbushet nevojat ditore. Te femrat shtatzënë të cilat nuk janë vegane nuk nevojiten suplemente pasi që mund mbushet nevoja ditore të vitaminës $\mathrm{B}_{12}$ nga produkte shtazore.

Ushqimet të pasura me vitamina $C$ rekomandohen të merren për absorbimin e suplementeve të hekurit. 
Ushqimet e pasura me hekur gjenden në mish të kuq,mish të pules,vezët,salmone dhe në produkte bimore sikurse tofu,spinaqi,pasuli,tërshëra.Kapaciteti i absorbimit të hekurit varet nga llojet e ushqimit dhe produktet shtazore absorbohet më lehtë .

Ushqimet që jane të pasura me kalcium zvogëlojnë absorbimin e hekurit pasi që kalciumi pengon absorbimin e hekurit.Prandaj nuk rekomandohet të merren suplemente të kalciumit apo ushqime të pasura me kalcium sikurse qumështi dhe produktet te saj dy orë para marrjes se suplementeve të hekurit dhe ushqimet e pasur me hekur.

Rekomandohet të eliminohet çajet e fermentuara(çaji i gjelbert, çaji i zi) dhe kafja zvogëlon absorbimin e hekurit.

Rekomandohet mishi i kuq 2 herë në javë dhe vezët 3-4 herë në javë ndërsa peshqit dy herë në javë, ndërsa peshqit të yndyrshëm sikurse salmoni,trofta së paku një herë në javë.

\begin{tabular}{|l|l|l|l|l|}
\hline Mëngjes & Midis shujte & Drekë & Midis shujte & Darkë \\
\hline $\begin{array}{l}\text { Jogurtë fruta dhe } \\
\text { tërshërë }\end{array}$ & Fruta arrore & $\begin{array}{l}\text { Supë kungull } \\
\text { Pasul }\end{array}$ & Sallatë frute & $\begin{array}{l}\text { Buke intregale me } \\
\text { tuna }\end{array}$ \\
\hline $\begin{array}{l}\text { Bukë intregal dhe } \\
\text { vezë }\end{array}$ & Sallatë frute & $\begin{array}{l}\text { Supë perime } \\
\text { Oriz me spinaq } \\
\text { dhe mish i bardhë } \\
\text { pule }\end{array}$ & Fruta arrore & Sallatë \\
\hline $\begin{array}{l}\text { Sallatë të thjeshtë } \\
\text { me vezë të zier }\end{array}$ & Fara & $\begin{array}{l}\text { Supe pule } \\
\text { Bullgur dhe } \\
\text { spinaq }\end{array}$ & Sallatë frute & Sardine \\
\hline
\end{tabular}

Table 9.Dieta për femrat shtatzënë me anemi

Ky tabelë është një shembull të dietës për femrat shtatzënë me anemi.

\subsection{Dieta vegjetariane për femrat shtatzëne̊}

Te dieta vegjetariane kemi të bëjmë me dietë ku nuk konsumohet mishi i kuq,mishi i pulës ose peshqi dhe kemi disa lloje të dietës vegjetariane sikurse:

- Lakto-vegjetarian është formë e dietës ku konsumohen vetëm produktet shtazore sikur qumështi dhe produktet të bylmetit. 
- Lakto-ovo-vegjetariane është formë e dietës ku konsumohen vetëm produkte shtazore sikurse produktet të qumështit, vezët dhe produkte ushqimore me vezë

- Ovo-vegjetariane është formë e dietës të cila konsumohet vetëm vezët si produkte shtatzore

- Pesko-vegjetariane është formë e dietës të cila konsumohet vetëm peshk si produkte shtatzore

Për femrat shtatzënë të cilat nuk konsumojnë qumësht dhe produktet të qumështit rekomandohet të konsumohen produktet të pasura me kalcium të cilat janë qumësht soje me kalcium,qumësht tërshëre me kalcium,arra,tofu dhe peshqit bashkë me eshtra sikur sardinet.Për femrat shtatzënë të cilat nuk konsumojnë peshqi dhe fruta të detit rekomandohet të konsumohen arrat,lajthiat,bademi,fisteku,farat lulediellit,farat kungulli, fara liri dhe marrja e suplementet të omegës-3 nga produkte bimore.Për femrat shtatzënë me dietë pesko-vegjetariane rekomandohet që proteinat të merren nga produktet bimore dhe së paku dy here në javë peshqi dhe poashtu për ovo-vegjetariane rekomandohet që proteina nga vezët,pasul,bizele dhe qiqra. Për femrat shtatzënë me dietës laktovegjetarian rekomandohet që proteina nga thjerrëza pasul,bizele ,qiqra dhe tofu.

\begin{tabular}{|l|l|l|l|l|}
\hline Mëngjes & Midis shujte & Drekë & Midis shujte & Darkë \\
\hline $\begin{array}{l}\text { Jogurtë fruta dhe } \\
\text { tërshërë }\end{array}$ & Sallatë frute & $\begin{array}{l}\text { Bullgur dhe } \\
\text { spinaq } \\
\text { Supë perime }\end{array}$ & Fruta arrore & Sallatë \\
\hline $\begin{array}{l}\text { Tërshërë me } \\
\text { kakao }\end{array}$ & Fruta arrore & $\begin{array}{l}\text { Thjerrëza } \\
\text { Supë këpurdhe }\end{array}$ & Fara kungulli & $\begin{array}{l}\text { Makarona me } \\
\text { djath }\end{array}$ \\
\hline
\end{tabular}

Table 10.Dieta lakto-vegjetariane për femrat shtatzënë

Për femrat shtatzënë me dietë lakto-vegjetariane rekomandohet që proteinat të merren nga produktet e bylmetit por edhe nga produkte bimore me shumë proteina sikurse pasuli,qiqra,thjerrëza,bizelja dhe soja me produtet të saj si tofu.Karbohidratet të merren nga ushqime të pasura me fibra dhe perime dhe midis shujta me fruta. Rekomandoj që omegën-3 të merret nga fruta arrore dhe fara të ndryshme sikurse fara liri dhe vaj liri,vaj lulediellit,vaj arre.

\begin{tabular}{|l|l|l|l|l|}
\hline Mëngjes & Midis shujte & Drekë & Midis shujte & Darkë \\
\hline
\end{tabular}




\begin{tabular}{|l|l|l|l|l|}
\hline $\begin{array}{l}\text { Bukë intregale } \\
\text { me tune dhe } \\
\text { sallatë }\end{array}$ & Fruta arrore & $\begin{array}{l}\text { Supë domate } \\
\text { Bullgur me } \\
\text { spinaq }\end{array}$ & $\begin{array}{l}\text { Fara kungulli } \\
\text { dhe lulediellit }\end{array}$ & Sallatë me tofu \\
\hline $\begin{array}{l}\text { Tërshërë me } \\
\text { qumësht tërshëre } \\
\text { dhe kakao }\end{array}$ & Sallatë frute & $\begin{array}{l}\text { Supë perime } \\
\text { Sallatë } \\
\text { Salmon me } \\
\text { perime }\end{array}$ & Fruta arrore & $\begin{array}{l}\text { Buke intregale } \\
\text { me tofu dhe } \\
\text { sallatë }\end{array}$ \\
\hline
\end{tabular}

Table 11.Dieta pesko-vegjetariane për femrat shtatzënë

Kjo tabelë është shembull për dietën pesko-vegjetariane për femrat shtatzënë.Rekomandoj që merret nga peshku së paku dy herë në javë dhe më shumë nga produktet bimore si bizele,qiqra,thjerrëza,pasuli.Omega-3 nuk është problem pasi që mund të merret nga peshqit dhe mund të merren edhe suplemente të omegës-3.

\begin{tabular}{|l|l|l|l|l|}
\hline Mëngjes & Midis shujte & Drekë & Midis shujte & Darkë \\
\hline $\begin{array}{l}\text { Tërshërë me } \\
\text { qumësht tërshëre } \\
\text { dhe fruta }\end{array}$ & Fruta arrore & $\begin{array}{l}\text { Supë perime } \\
\text { Thjerrëza }\end{array}$ & Fara kungull & $\begin{array}{l}\text { Buke intregale } \\
\text { me vezë të zier } \\
\text { dhe sallatë }\end{array}$ \\
\hline $\begin{array}{l}\text { Buke intregale } \\
\text { me vezë të zier } \\
\text { dhe sallatë }\end{array}$ & Sallatë frute & $\begin{array}{l}\text { Supë këpurdhe } \\
\text { Pasul }\end{array}$ & Fruta arrore & Makarona \\
\hline
\end{tabular}

Table 12.Dieta ovo-vegjetariane për femrat shtatzënë

Kjo tabelë eshtë shembull për dietën ovo-vegjetariane për femrat shtatzënë.Rekomandoj që proteinat të merren nga pasuli,thjerrëza,qiqra dhe për vezë se paku katër herë në javë.Omega-3 mund të merret nga fruta arrore, fara,vajra dhe suplimente.

\subsection{Dieta vegane për femrat shtatzënë.}

Dieta vegane është formë e dietës ku nuk konsumohet mishi(mish i kuq,mishi i pulës,peshku), produktet shtazore dhe produktet ushqimore të cila përmbajnë produkte shtatzore.

Për femrat shtatzënë me dietë vegane rekomandohet që të konsumohen produktet bimore të pasura me vitaminën $\mathrm{C}$ pasi rrit absorbimit të hekurit nga produkte bimore të pasura me hekur . Ndërsa produktet që zvogëlojnë absorbimit të hekurit të cilat janë suplemente të kalciumit, kafe dhe qaj i fermentuar. 
Për femrat shtatzënë me dietë vegane rekomandohet që proteinat të merret nga produktet bimore të cilat janë soja,tofu,djathi vegan,bizelja,pasuli,qiqra dhe sasia e proteinës nuk ndryshon nga dieta e femrave shtatzënë jo vegane.

Rekomandohet të merren suplemente të vitaminës $B_{12}$ për femrat shtatzënë me dietën vegane pasi që produktet bimore kanë sasi të vogël.Kemi produkte ku te cilat i'a shtuar vitaminat $\mathrm{B}_{12}$ si qumështë soje,nutritional yeast.

Te dietat vegane merren folatet nga ushqimet si buka,pasta,perimet dhe pemët por edhe pse kjo dietë është e pasur me folate por për siguri rekomandohet suplementet $400 \mathrm{mg} /$ ditë.Femrat shtatzënë me dietë vegane duhet të marrin vitamin D si suplemente në sasi 600 IU sidomos nëse nuk mund ekspozohen në dritë të diellit. Një pjesë e vitaminës D mund të merret në produkte të sojës.

Omega -3(acidi linolenik) mund të gjendet në fara të ndryshme(arra,lajthi,liri,badem), vajra sikur vaji i lulediellit,ullirit dhe vaji i lirit dhe për femrat shtatzënë me dietë vegane mund të merret si suplement omega-3 nga produkte bimore.

\begin{tabular}{|l|l|}
\hline & Proteina $/ 100 \mathrm{~g}$ \\
\hline Qiqra & $8.75 \mathrm{~g}$ \\
\hline Tofu & $10.13 \mathrm{~g}$ \\
\hline Soja & $9.86 \mathrm{~g}$ \\
\hline Thjerrëza & $28.57 \mathrm{~g}$ \\
\hline Table 13.Sasia e proteina në produkte bimore nga USDA
\end{tabular}

Pasi që retinoli gjendet në produkte shtazore dhe për femrat shtatzënë vegan nevojitet rritet sasia e karatenoideve apo beta-karoteni të cila gjendet në produkte bimore .

\begin{tabular}{|l|l|l|l|l|}
\hline Mëngjes & Midis shujte & Drekë & Midis shujte & Darkë \\
\hline
\end{tabular}




\begin{tabular}{|l|l|l|l|l|}
\hline $\begin{array}{l}\text { Bukë intregale dhe } \\
\text { tofu }\end{array}$ & Ftuta arrore & Supë këpurdhe & Sallatë fruta & Sallatë \\
\hline $\begin{array}{l}\text { Tërshërë me } \\
\text { qumështë tërshëre } \\
\text { dhe kakao }\end{array}$ & Sallatë fruta & Bizele me perme & Fara kungulli & Sallatë me tofu \\
\hline Sallatë me tofu & Fruta arrore & Sallatë & Fara lulediellit & \\
& & Qiqra & Fruta kungulli & Soja të pjekura \\
\hline
\end{tabular}

Table 14.Dieta vegane për femra shtatzënë

\section{Pjesa praktike}

Qëllimi i pjesës të punës praktike është të vlerësoj mënyrën e të ushqyerit të katër femrave shtatzënë. Në pjesën praktike kam studiuar konsumimin e makronutrientëve dhe mikronutrientëve me anë të ditarit ushqimore për tre ditë.Logaritjet janë bërë me anë të Nutritionix Database dhe Nutrition values .

\subsection{Ditari ushqimore për tre ditë për pacientën e parë}

Ky është ditari ushqimore treditore të pacientës në muajin e gjashtë

\begin{tabular}{|c|c|c|c|}
\hline Shujta & Dita 1 & Dita 2 & Dita 3 \\
\hline $\begin{array}{l}\text { Mëngjesi } \\
\text { (Shujta e parë) }\end{array}$ & $\begin{array}{l}\text { Lëng protokalli }(100 \mathrm{ml}) \\
\text { Dy vezë të zierë } \\
\text { Patate e ëmbel }\end{array}$ & $\begin{array}{l}\text { Lëng protokalli (100ml) } \\
\text { Avokado tost }\end{array}$ & $\begin{array}{l}\text { Lëng protokalli }(100 \mathrm{ml}) \\
\text { Tërshërë me fruta dhe fara } \\
\text { chia }\end{array}$ \\
\hline Midis shujta & Banane & $\begin{array}{l}\text { Jogurt me fruta } \\
\text { Molla }\end{array}$ & Jogurt grek me pemë \\
\hline $\begin{array}{l}\text { Dreka } \\
\text { (Shujta e dytë) }\end{array}$ & $\begin{array}{l}\text { Karota, brokoll,kungullesh } \\
\text { dhe patlixhan i zi të zier } \\
\text { Jogurtë }\end{array}$ & $\begin{array}{l}\text { Oriz me perime dhe mish } \\
\text { pule }\end{array}$ & $\begin{array}{l}\text { Supë këpurdhe } \\
\text { Boronija me mish viqi } \\
\text { Sallate te gjelberte }\end{array}$ \\
\hline Midis shujta & $50 \mathrm{~g}$ arra & $\begin{array}{l}\text { 50g fara kungulli dhe fara } \\
\text { luledielli }\end{array}$ & $50 \mathrm{~g}$ badem \\
\hline
\end{tabular}




\begin{tabular}{|l|l|l|l|}
\hline $\begin{array}{l}\text { Darkë } \\
\text { (Shujta e tretë) }\end{array}$ & $\begin{array}{l}\text { Quinoa } \\
\text { Sallatë cesar } \\
\text { Qumësht bademi }\end{array}$ & $\begin{array}{l}\text { Sallatë pule } \\
\text { Qumësht bademi }\end{array}$ & Quinoa \\
& & & \\
\hline
\end{tabular}

Table 15.Ditar ushqimorë për tre ditë të pacientit të parë

Në mëngjes të ditës të parë kemi lëng protokalli(100 ml),dy vezë të zierë dhe patate e ëmbël(100g), te cilat komplet kanë $277 \mathrm{kcal}, 28 \mathrm{~g}$ karbohidrate, proteina $14 \mathrm{~g}$ dhe $10.6 \mathrm{~g}$ yndyrë.Nga vezet marrim $1.9 \mathrm{mg}$ Fe dhe $2.3 \mathrm{mcd}$ vitamin D.

Në dy midis shujta kemi molla të cilat kanë vitamina $C$ dhe 95 kalori, ndërsa midis shujta kemi $50 \mathrm{~g}$ arra me $442 \mathrm{kcal}, 33 \mathrm{~g}$ yndyra dhe $3.4 \mathrm{~g}$ fibra.Në darkë kemi quinoa me 120 kalori dhe $21 \mathrm{~g}$ karbohidrate,sallata cesasar që ka 40 kcal.

Sasia totale e kalorive jane $1019 \mathrm{kcal}, 77 \mathrm{~g}$ karbohidrate,43,6 ,proteina $14 \mathrm{~g}$ dhe fibra $3.4 \mathrm{~g}$.

Në ditën e dytë ne mengjes kemi përseri lëng protokalli me $40 \mathrm{kcal}$ dhe $4 \mathrm{~g}$ karbohidrate dhe avokado tost të cila kemi $11 \mathrm{~g}$ yndyre dhe $20 \mathrm{~g}$ karbohidrate me $5.4 \mathrm{~g}$ fibra.Në midis shujte kemi molla me $95 \mathrm{kcal}$ dhe $25 \mathrm{~g}$ karbohidrate dhe jogurte me fruta që ka $162 \mathrm{kcal}, 32 \mathrm{~g}$ karbohidrate dhe $7.5 \mathrm{~g}$ proteina.Ndërsa midis shujtën e dyte kemi $25 \mathrm{~g}$ fara lulediellit dhe $25 \mathrm{~g}$ fara kungullit të cilat kanë 117 kcal.

Në drekë kemi oriz me perime dhe mish pule të cilat kanë $451 \mathrm{kcal}, 54,7 \mathrm{~g}$ karbohidrate,4,3 g yndyre dhe $37 \mathrm{~g}$ proteina.Në darkë kemi sallatë pule dhe qumësht bademi të cilat kanë $282 \mathrm{kcal}$ ,18g yndyre,14g proteina dhe 7.3 karbohidrate. Sasia totale e kalorive $1052 \mathrm{kcal}, 118 \mathrm{~g}$ karbohidrate, $30 \mathrm{~g}$ yndyre dhe $61.5 \mathrm{~g}$ proteina.

Në ditën e tretë kemi përseri lëng protokalli me $40 \mathrm{kcal}$ dhe $4 \mathrm{~g}$ karbohidrate dhe tërsherë me fruta dhe fara chia të cilat kanë $403 \mathrm{kcal}, 59,1$ karbohidrate të cilat kanë $8.2 \mathrm{~g}$ fibra,10.3g yndyrë 12,6g proteina.Në midis shujte kemi jogurt grek me fruta e cila ka 68 kcal me 11g karbohidrate dhe 5.9 g proteina.Në drekë: supe kepurdhë,sallatë të gjelbërt dhe boronija me mish viqi të cilat kanë 380 kcal ,14.4 karbohidrate,25g proteina dhe 8.2g yndyrë.Midis shujta e dytë janë bademat dhe kanë $290 \mathrm{kcal}, 25 \mathrm{~g}$ yndyre,11g karbohidrate me $6.6 \mathrm{~g}$ fibra dhe $11 \mathrm{~g}$ proteina.Ne darkë kemi quinoa me $120 \mathrm{kcal} 21 \mathrm{~g}$ karbohidrate $1.9 \mathrm{~g}$ yndyre dhe $4.4 \mathrm{~g}$ proteina Sasia totale jane $1301 \mathrm{kcal}, 116.5 \mathrm{~g}, 58,9$ g proteina dhe $21.8 \mathrm{~g}$ yndyre.Në përgjithesi sasia e kalorive është mirë.Kemi ushqime me fibra 
dhe sasi jo të tepruar të produkteve shtazore. Kemi fruta të cilat plotësojnë vitaminat B,vitaminat D dhe C. Rekomandoj që mish pule të hahet dy herë në javë dhe një herë mish lope. Sasia e fibrave rekomandohet të jetë deri në $20 \mathrm{~g}$ e cila merret nga ushqimet sikurse bulgur,quinoa,makarona intregale dhe bukë intregale.Për proteina të merret pjesa më e madhe nga produktet bimore.Vezë së paku 4 copa dhe djath ne sasi të limituar sidomos djath me yndyrë të plotë.

\subsection{Ditari ushqimore për tre ditë për pacientën e dytë}

\begin{tabular}{|l|l|l|l|}
\hline Shujta & Dita 1 & Dita 2 & Dita 3 \\
\hline $\begin{array}{l}\text { Mëngjesi } \\
\text { (Shujta e parë) } \\
\text { Tost me gjalpë kikirikave }\end{array}$ & $\begin{array}{l}\text { Smoothie me fruta dhe } \\
\text { jogurt }\end{array}$ & $\begin{array}{l}\text { Kafe } \\
\text { Tërshërë me fruta tropikale }\end{array}$ \\
\hline $\begin{array}{l}\text { Midis shujta } \\
\text { Dreka }\end{array}$ & Banana & badem & Sallatë frute \\
\hline $\begin{array}{l}\text { Shujta e dytë) } \\
\text { sojës dhe pure patate }\end{array}$ & $\begin{array}{l}\text { Sallatë me domate,tranguj } \\
\text { dhe djath } \\
\text { Supë perime } \\
\text { Biftek }\end{array}$ & $\begin{array}{l}\text { Supë këpurdhe } \\
\text { File pule me asparagus }\end{array}$ \\
\hline $\begin{array}{l}\text { Midis shujta } \\
\text { (Shujta e tretë) }\end{array}$ & $\begin{array}{l}\text { Mollë } \\
\text { Dardhe }\end{array}$ & $\begin{array}{l}\text { Sanduiq të pulës } \\
50 \text { copa të qokollatë të zezë }\end{array}$ & $\begin{array}{l}\text { Rrush } \\
\text { Badem }\end{array}$ \\
\hline
\end{tabular}

Table 16.Ditar ushqimore për tre ditë nga pacientja e dytë

Në ditën e parë kemi kafe dhe tost me gjalpë kikiriku të cilat kanë 510 kcal,26g yndyrë,54 g karbohidrate me $5 \mathrm{~g}$ fibra dhe $18.2 \mathrm{~g}$ proteinat.Në midis shujte kemi banana me $105 \mathrm{kcal}, 27 \mathrm{~g}$ karbohidrate, $1.3 \mathrm{~g}$ proteina. 
Në drekë kemi krahe pule me salse soje dhe pure të patetes të cilat kanë $388.3 \mathrm{kcal}, 22.8 \mathrm{~g}$ karbohidratet, $16.5 \mathrm{~g}$ proteina dhe $25.5 \mathrm{~g}$ yndyre.

Në midis shujtë kemi një molle dhe një dardhë kemi 140,5 kcal dhe $38.5 \mathrm{~g}$ karbohidrate me fibra 8.8g.Në darkë kemi sanduiq pule kemi 468 kcal,21g yndyrë,39g karbohidrate $30 \mathrm{~g}$ proteina.Sasia totale janë $1611,8 \mathrm{kcal}, 181.8 \mathrm{~g}$ karbohidrate,66g proteina,72,5 g yndyrë.

Në ditën e dytë për mëngjes kemi smoothie me fruta dhe jogurt me $161 \mathrm{kcal}, 1.7 \mathrm{~g}$ yndyrë,34g karbohidrate dhe $5.5 \mathrm{~g}$ proteina.Në midis shujte kemi 8 copa badem të cilat kanë $61.6 \mathrm{kcal}, 5.4 \mathrm{~g}$ yndyre, $2.2 \mathrm{~g}$ karbohidrate me $1.1 \mathrm{~g}$ fibra dhe proteina $2.2 \mathrm{~g}$.

Në drekë kemi biftek,sallatë dhe supë perime të cila kanë $408.8 \mathrm{kcal}, 24.6 \mathrm{~g}$ yndyrë,13 g karbohidrate dhe $32.2 \mathrm{~g}$ proteina.Në midis shujte kemi 2 copa qokollatë dhe $50 \mathrm{~g}$ brusnica të cilat kanë 103 kcal,30g karbohidrate,8.5 yndyrë.Dhe në darkë kemi sallatë të frutave 50 kcal.Sasia totale $784.4 \mathrm{kcal}, 49.3 \mathrm{~g}$ karbohidrate,39.9 kcal dhe $28.6 \mathrm{~g}$ yndyrë.

Ditën e tretë kemi kafe me tërsherë dhe fruta tropikale kemi $354.5 \mathrm{kcal}, 66 \mathrm{~g}$ karbohidrate të cilat kanë $8.4 \mathrm{~g}$ fibra, $10,6 \mathrm{~g}$ proteina dhe $5,2 \mathrm{~g}$ yndyrë.

Midis shujte kemi sallatë dhe janë 40 kcal.Në drekë kemi supë këpurdhe dhe filetë pule me asparagus kemi $330 \mathrm{kcal}, 39 \mathrm{~g}$ proteina,12,3g yndyrë,10.3 karbohidrate.Në midis shujte kemi rrush dhe badem të cilat janë $109.2 \mathrm{kcal}, 14,2 \mathrm{~g}$ karbohidrate me $1.1 \mathrm{~g}$ fiber,2.2g proteina.

Në darkë kemi bukë misri me spinaq kemi 198 kcal,6g yndyrë,33g karbohidrate dhe 4g proteina.Sasia totale është $922.5 \mathrm{kcal}, 109.3 \mathrm{~g}$ karbohidrate,55.8 g proteina dhe $18.3 \mathrm{~g}$ yndyrë.

Kur kemi të bëjmë me sasinë ditore të kalorive ,dita e parë ka më shumë kalori por dy ditët tjera me pak kalori se do të rekomandoja .Për kosumimin e kafeve lejohet vetëm 200 mg kafeinë e cila mund të jetë maksimumi dy ekpresso.Nuk rekomandohet për shkak të rrezikut të lindjes të fëmijës me peshë të ulët.Rekomandoj limitimin e sasinë së kafeinën nese mundet 1 ekspresso apo makiato ndërsa nese keni mundesi mund të perdoret decaff kafe e cila sasi më e vogël me $3 \mathrm{mg}$.

Limitim të ushqime të fërguar pasi që kanë sasi të lartë të yndyrave të ngopura, por rekomandoj fruta arrore dhe fara.Midis shujtave frutat arrore dhe frutat të ndryshme janë ideale për marrjen e 
vitaminat e nevojshme dhe omega-3.Rekomandoj të rritet sasia e karbohidrate sikurse shujta me makarona intregale me perime, bukë integrale, bulgur me perime dhe quinoa.

\subsection{Ditari ushqimore për tre ditë për pacientën e tretë}

Pacienta është në muajin e tetë të shtatzanisë

\begin{tabular}{|c|c|c|c|}
\hline Shujta & Dita 1 & Dita 2 & Dita 3 \\
\hline $\begin{array}{l}\text { Mëngjesi } \\
\text { (Shujta e parë) }\end{array}$ & $\begin{array}{l}\text { Dy rriska bukë intregrale } \\
1 \text { vezë e zier dhe } 60 \mathrm{~g} \\
\text { djath }\end{array}$ & Tërshërë me pemë & $\begin{array}{l}1 \text { vezë ,djath } 60 \mathrm{~g} \\
2 \text { riska bukë intregal }\end{array}$ \\
\hline Midis shujta & $\begin{array}{l}1 \text { mollë,1 dardhë,1 } \\
\text { banane }\end{array}$ & $30 \mathrm{~g}$ arra & 20g qokollatës \\
\hline $\begin{array}{l}\text { Dreka } \\
\text { (Shujta e dytë) }\end{array}$ & $\begin{array}{l}\text { Supë këpurdhe } \\
\text { Sallatë } \\
\text { Bulgur me mish të bardhë }\end{array}$ & $\begin{array}{l}\text { Supë pule } \\
\text { Oriz me perime }\end{array}$ & $\begin{array}{l}\text { Makarona me salcë spinaqi } \\
\text { dhe arra } \\
\text { Supë perime }\end{array}$ \\
\hline Midis shujta & 30g lajthi & Jogurt me fruta & Banana \\
\hline $\begin{array}{l}\text { Darkë } \\
\text { (Shujta e tretë) }\end{array}$ & Leqenik me spinaq & Sallatë me djath & 2 rriska me avokado \\
\hline
\end{tabular}

Table 17.Ditar ushqimore për tre ditë nga pacienta e tretë

Në diten e parë për mengjes kemi dy riska buke intregale, 1 vezë dhe $60 \mathrm{~g}$ djath të cilat kanë $423 \mathrm{kcal} 22 \mathrm{~g}$ yndyrë, $14.5 \mathrm{~g}$ proteina dhe $28 \mathrm{~g}$ karbohidrate.Në midis shujte kemi 1 mollë, 1 dardhë dhe 1 banane dhe kemi 203 kcal dhe 53g karbohidrate.Në drekë kemi supë këpurdhe,sallatë dhe bulgur me mish të bardhë kemi 424kcal,39.1g proteina,6.8g yndyra.Në midis shujte janë $30 \mathrm{~g}$ lajthi kane $183 \mathrm{kcal}, 18 \mathrm{~g}$ yndyre,5g karbohidrate dhe $4.3 \mathrm{~g}$ proteina.Në darkë kemi leqenik e cila është $283 \mathrm{kcal}$.Sasia totale kemi $1333 \mathrm{kcal}, 81 \mathrm{~g}$ karbohidrate,40g yndyrë,57.9g proteina.

Në ditën e dytë për mengjes kemi tërsherë me fruta kanë $346 \mathrm{kcal} 5.2 \mathrm{~g}$ yndyrë,58 g karbohidrate të cilat kanë $8.2 \mathrm{~g}$ fibra dhe $10.6 \mathrm{~g}$ proteina.Në midis shujtë janë 30g arra janë $195 \mathrm{kcal}, 19.5$ yndyrë,4.2g karbohidrate të cilat janë fibrat $2.1 \mathrm{~g}$ dhe $4.7 \mathrm{~g}$ proteina. 
Në midis shujtë kemi jogurt me fruta të kanë $162 \mathrm{kcal}, 32 \mathrm{~g}$ karbohidrate dhe $7.5 \mathrm{~g}$ proteina.Në darkë me sallatë me djath e cila ka $320 \mathrm{kcal}, 2 \mathrm{~g}$ karbohidrate,20g yndyrë dhe 22g proteina.Sasia totale ditore janë $1023 \mathrm{kcal}, 64.2 \mathrm{~g}$ karbohidrate, $39.5 \mathrm{~g}$ yndyrë dhe $22.8 \mathrm{~g}$ proteina.Në ditën e tretë për mëngjes dy riska bukë intregale, 1 vezë dhe $60 \mathrm{~g}$ djath kemi $423 \mathrm{kcal} 22 \mathrm{~g}$ yndyrë, $14.5 \mathrm{~g}$ proteina dhe $28 \mathrm{~g}$ karbohidrate.Në midis shujte kemi $20 \mathrm{~g}$ qokollatë të zezë dhe janë $120 \mathrm{kcal}, 8.5$ g yndyrë, $9.2 \mathrm{~g}$ karbohidrate dhe $1.6 \mathrm{~g}$ proteina.Në drekë janë supë perime dhe makarona me salsë spinaq kanë $404 \mathrm{kcal} 46.8 \mathrm{~g}$ karbohidrate, $8 \mathrm{~g}$ proteina dhe $5.8 \mathrm{~g}$ yndyrë.Në darkë kemi dy riska me avokado të cilat kanë $189 \mathrm{kcal}, 11 \mathrm{~g}$ yndyrë,20g karbohidrate dhe sasia e fibrave është 5.4g.Sasia totale ditore është $1136 \mathrm{kcal}, 104 \mathrm{~g}$ karbohidrate, $25.3 \mathrm{~g}$ yndyrë dhe $24.1 \mathrm{~g}$ protein. Sasia e kalorive janë rregullt.Proteinat rekomandoj të merrren nga produktet bimore tofu soja,qiqra,pasul,thjerrëza dhe pulë dy herë në javë.Omega-3 mund marrim me dy herë në javë peshqit dhe si shohim në dietë omega-3 është marrur nga fruta arrore.Shujta të shpeshta me fruta dhe perime mund të ndihmoj me vitaminat B si folate,acid. folik dhe fibra të cilën rekomandoj të jetë $20 \mathrm{~g}$ për nevojë ditore.Rekomandoj limitimi të pije freskuese dhe të pihet më shumë lëngje pa sheqer të shtuar,qajra dhe supa përveq qajit të gjelbërtë,i zi ,kamomil dhe kantarion .

3.4 Ditari ushqimore për tre ditë për pacientën e katërt

Pacienta është muajin e tretë të shtatzanisë.

\begin{tabular}{|l|l|l|l|}
\hline Shujta & Dita 1 & Dita 2 & Dita 3 \\
\hline $\begin{array}{l}\text { Mëngjesi } \\
\text { (Shujta e parë) }\end{array}$ & $\begin{array}{l}\text { 2 vezë ,mocarrella } \\
2 \text { rriska bukë të bardhë }\end{array}$ & $\begin{array}{l}\text { Bukë me avokado } \\
1 \text { gotë qumësht }\end{array}$ & $\begin{array}{l}\text { Tërshërë me fruta dhe } \\
\text { qokollatë e zezë }\end{array}$ \\
\hline Midis shujta & 1 mollë,1 banane & $30 \mathrm{~g}$ badem & Jogurt me fruta \\
\hline $\begin{array}{l}\text { Dreka } \\
\text { (Shujta e dytë) }\end{array}$ & $\begin{array}{l}\text { Supë të thjeshtë } \\
\text { Sallatë }\end{array}$ & $\begin{array}{l}\text { Supë pule } \\
\text { Bullgur me } \\
\text { karotë,kungulleshë }\end{array}$ & $\begin{array}{l}\text { Supë perime } \\
\text { Makarona intregale me salsë } \\
\text { domate dhe mish bluar lopës }\end{array}$ \\
\hline Midis shujta & Banana & 30 gqokollatë të zezë & Molla \\
\hline $\begin{array}{l}\text { Darkë } \\
\text { (Shujta e tretë) }\end{array}$ & Bukë misri me qumështë & Drithëra me fara të lirit,arra & Bukë me avokado \\
\hline
\end{tabular}




\section{Table 18.Ditar ushqimore për tre ditë nga pacientja e katër}

Në ditën e parë për mëngjes kemi dy vezë,60g djath dhe dy riska të bukës së bardhë janë 437 kcal ,19g yndyrë,36 g karbohidrate dhe 25.2 g proteinë.Në midis shujte kemi një mollë,një banane janë $178 \mathrm{kcal}, 35.8 \mathrm{~g}$ karbohidrate dhe $2.4 \mathrm{~g}$ proteina.Në darkë kemi supë të thjeshtë, sallatë dhe oriz me spinaq janë $374 \mathrm{kcal}, 39.7 \mathrm{~g}$ karbohidrate,20.5g yndyrë dhe $10 \mathrm{~g}$ proteina.Në midis shujte kemi banane të cilat kanë $126 \mathrm{kcal}, 21 \mathrm{~g}$ karbohidrate dhe $1 \mathrm{~g}$ protein.Në darkë kemi bukë misri me qumësht janë $248 \mathrm{kcal}, 36.3 \mathrm{~g}$ karbohidrate ,8.8g proteina dhe $9.3 \mathrm{~g}$ yndyrë.Në ditën e dytë për mëngjes kemi 1 risk avokado toast me vezë dhe qumësht janë $380 \mathrm{kcal}, 31.8 \mathrm{~g}$ karbohidrate,18g yndyrë dhe $21.3 \mathrm{~g}$ protein.Në midis shujte kemi $30 \mathrm{~g}$ badem janë $161.7 \mathrm{kcal}$, $14.3 \mathrm{~g}$ yndyrë,5.7g karbohidrate dhe $5.7 \mathrm{~g}$ proteina .Në drekë kemi supë pule,bulgur me karotë, kungulleshë, bizele janë $486 \mathrm{kcal}, 5.2 \mathrm{~g}$ yndyrë, $15 \mathrm{~g}$ proteina dhe $86.6 \mathrm{~g}$ karbohidrate të cilat sasia e fibrave është $18 \mathrm{~g}$ të cila vjen nga bullguri.Në midis shujte kemi qokollatë janë $170 \mathrm{kcal}$ ,12 g yndyrë,13 g karbohidrate dhe $2.2 \mathrm{~g}$ proteina. Në shujtë e darkës kemi drithëra me arra dhe fara liri dhe janë $334 \mathrm{kcal}, 5.9 \mathrm{~g}$ yndyrë,58.7 $\mathrm{g}$ karbohidrate dhe $15 \mathrm{~g}$ proteina.Sasia totale ditore janë 1361.7 kcal, 190.1 karbohidrate,41.1 yndyrë dhe 57 g proteina.

Në ditë të tretë për mëngjes kemi tërshërë me fruta dhe qokollatë të zezë të cilat janë 369 kcal ,4.9 g yndyrë,70.5g karbohidrate me $8.8 \mathrm{~g}$ fibra dhe $8.4 \mathrm{~g}$ proteina.Në midis shujte jogurt me fruta janë $95 \mathrm{kcal}, 19 \mathrm{~g}$ karbohidrate dhe $4.4 \mathrm{~g}$ protein.Në drekë kemi shpageta me salsë domate me mish të bluar janë $117.6 \mathrm{kcal}, 2.4 \mathrm{~g}$ yndyrë,19.3g karbohidrate dhe $4.2 \mathrm{~g}$ protein.Në midis shujte kemi molla janë $95 \mathrm{kcal}, 25 \mathrm{~g}$ karbohidrate.Në darkë 1 risk bukë me avokado e cila ka $189 \mathrm{kcal}, 11 \mathrm{~g}$ yndyrë,20g karbohidrate dhe $3.8 \mathrm{~g}$ proteina.Sasia totale ditore është $865.6 \mathrm{kcal}, 128.8 \mathrm{~g}$ karbohidrate,7.3g yndyrë dhe 19.9 g proteina.Sasia e kalorive janë mire përveq ditës të tretë të cila ka me pak kalori nga dy ditë të japur.Marrja e fibrave nga tërshëra , bukë intregale janë të nevojshme pasi ndihmojnë tretje e ushqimit dhe sistemin e tretjes. Shujta me sasi të vogël por me fruta të ndryshme sikurse molla,banana dhe fruta arrore ndihmojnë për përmbushje të sasinë të nevojshme të vitaminat të kompleksit B,vitaminën C,omega-3,vitaminën E.Për shujtën e darkës rekomandoj sasi më të vogël të kalorive sidomos produktë me yndyrë dhe shujta të jetë më vogël. Rekomandoj që proteinat të merren nga produktet bimore sikurse soja,tofu,pasul,qiqra,thjerrëza dhe pule, peshqi të merren dy 
herë në javë.Yndyra rekomandoj të merret nga avokado, fruta arrore dhe vajra të ndryshme dhe limitimi i yndyrës të ngopura e cila gjendet në mish lope,lëkurës të mishit të pulës dhe produkte shtazore sikurse suxhuku,sallami dhe vishllja.

\section{Konkulzione}

Mënyra e të ushqyerit ndikon në rritjen e fetusit dhe shëndetin e femrës shtatzënë si dhe shtimit të peshës gjatë shtatzanisë. Aktivitetet fizike për femrat shtatzënë ndihmojnë në shtimin normal të peshës,humbje graduale të peshës pas shtatzanisë dhe aktiviteti fizikë mund të jetë të lehtë dhe mesatare së paku 30min në ditë.

Sasia e kalorive ndryshon se paku 340 kcal apo një shujtë ndërsa 500 kcal për femrat shtatzënë të cilat janë nënpeshë,adoleshence apo femrat me dy e më shumë fetus dhe nuk nevojitet të rritet më shumë sasia e ushqimeve vetëm ndryshim i mënyrës të ushqyerit.Sasia e karbohirateve nuk ndryshon por marrja e karbohidrateve prej fruta, perime dhe ushqimet të pasura me fibra.Poashtu sasia e yndyrës nuk ndryshon por rekomandoj që të merret nga vajrat, farat dhe fruta arrore dhe limitimi i yndyrës së ngopura e cila vjen nga produktet shtazore.Sasia e proteinave ndryshon pasi nevojitet për rritjen e qeliza e reja për fetusit dhe femrën shtatzënë.Rekomandoj që proteinat të merret $2 / 3$ nga produkte bimore dhe $1 / 3$ nga produkte shtazore.Vitaminat lipofile merren nga produkte shtazore,vajërat,farat dhe frutat arrore.Vitamina hidrofile merret nga fruta dhe perime të ndryshme.Mënyra e të ushqyerit e shëndeshme për femrat shtatzënë me sëmundje të caktuara si diabeti,kolesteroli i lartë, ndihmon shëndetin e femrës shtatzënë dhe për femrat shtatzënë që dëshirojnë të mbajnë dieta vegane dhe vegjetariane të konsultohen me dietolog për përmbushjen e nevojat ditore të nutrientëve. Në përfundim mund të themi se si ushqehemi ndikon në shëndetin e femrës shtatzënë dhe të fëmijës.

\section{Biblografia}

[1]Carol J.L,Sarah C.C,Elliot H.P Handbook of Nutrition and Pregnancy Botimi.Humana Press,2008ＩSBN:9781597451123, 1597451126

[2]Proper Maternal Nutrition during Pregnancy Planning and Pregnancy,2017 https://www.euro.who.int/ data/assets/pdf file/0003/337566/Maternal-nutrition-Eng.pdf?ua=1 
[3]Food and Nutrition Guidelines for Healthy Pregnant and Breastfeeding Women: A background paper,2006

https://www.health.govt.nz/system/files/documents/publications/food-and-nutrition-guidelines-pregand-bfeed.pdf

[4]Gestational Diabetes and Pregnancy

https://www.cdc.gov/pregnancy/diabetes-gestational.html

[5] Gestational Diabetes and Pregnancy

https://www.diabetes.org/diabetes/gestational-diabetes

[6]Pregnancy and the Vegan Diet

https://www.vrg.org/nutrition/veganpregnancy.php

[7]Why is Omega-3 Fish Oil Important During Pregnancy?

https://americanpregnancy.org/pregnancy-health/omega-3-fish-oil-and-pregnancy/

[8]Nutritionix Database https://www.nutritionix.com/database

[9]Nutrition values https://www.nutritionvalue.org/ 